\title{
Factors Affecting the Selection of Human Resources \\ Management as an Area of Specialization: A Conceptual Model
}

\author{
Fernando W.S.K, \\ Department of Business Management, SLIIT Business School \\ Sri Lanka Institute of Information Technology, Malabe, Sri Lanka
}

Jayasekara M.K.V.R,

Department of Business Management, SLIIT Business School

Sri Lanka Institute of Information Technology, Malabe, Sri Lanka

Sumanarathne W.G.G.M.J,

Department of Business Management, SLIIT Business School

Sri Lanka Institute of Information Technology, Malabe, Sri Lanka

Senevirathne H.B.M.C,

Department of Business Management, SLIIT Business School

Sri Lanka Institute of Information Technology, Malabe, Sri Lanka

Pathirana G.Y,

Department of Business Management, SLIIT Business School

Sri Lanka Institute of Information Technology, Malabe, Sri Lanka

Weerarathna R.S

Department of Business Management, SLIIT Business School

Sri Lanka Institute of Information Technology, Malabe, Sri Lanka

Received: Nov. 8, 2020 Accepted: Dec. 7, 2020 Online published: Dec. 23, 2020

doi:10.5296/ijhrs.v11i1.18102 URL: https://doi.org/10.5296/ijhrs.v11i1.18102 


\section{Abstract}

In modern times, the trends in students' choice of specialization in the bachelor's degree are changing rapidly. Therefore, this research study attempts to build a conceptual framework to uncover the relationship between students' choice of specialization in Human Resources Management (HRM) and the factors that influence students' decision making when selecting the area of specialization. This concept paper examines the independent variables (influential factors) which impact the selection of HRM as an area of specialization. The conceptualization supports the theoretical framework created to identify the personal factors, academic factors and social factors which lead to the selection of the area of specialization. The primary importance of this paper is that the conceptual framework can be used in other countries for academic purposes.

Keywords: personal factors, academic factors, social factors, human resources management

\section{Introduction}

University students make many decisions during their academic careers. However, selecting a major for their university degree is one of the most important and influential decisions they have to make. Selecting an academic major affects their subsequent career progress as well. Awareness regarding students' individual choices of majors is vital for the effective allocation of human resources. Sometimes, the decisions that undergraduates make might not suit their capabilities and personal characteristics. Therefore, if undergraduates make correct decisions regarding their academic major, it may help to reduce barriers to their career progress. This life changing decision has policy implications as well. There are a wide variety of degree programs offered in universities. Each degree program offers several majors or areas of specialization. Some majors need more theoretical knowledge while others require more practical skills. In addition, choosing some areas of specialization are riskier than choosing others. There is a prevalent opinion among some students that following a riskier major for their degree program will ensure subsequent career success and lead to higher earnings in the future. However, making riskier choices of specialization sometimes leads to failure. Researchers have found that introducing college majors that will provide good earning opportunities in the future could attract more students to these majors than to others (Duru and Mingat, 1979).

Selecting an academic major is an important and sometimes very difficult choice for students because it affects their future personal goals and career goals. Some universities have identified the need for conducting academic consultation programs, because they are ultimately responsible for students' academic life. These guidance programs are conducted with the joint interaction and participation of undergraduates, industrial professionals, recruiters and professors. Here, students can discuss their problems regarding selection of college majors and take appropriate decision by considering their capabilities, unique interests and needs, with the guidance of consultants. Awareness of factors affecting the choice of academic majors and minors helps students plan degree offerings (Stock and Stock, 2019). According to past studies done by Duru and Mingat (1979) and Stock and Stock (2019) selecting an appropriate area of specialization which suits their individual preferences is the 
most influential decision that university students take in their university careers. This decision not only affects their individual academic lives but their future personal lives as well. Future personal life includes satisfaction, career opportunities, and employment opportunities, continuity of academic life, financial stability, financial status and social status. "Good" selection of a business specialization opens up better paths to achieve students' educational goals according to their capabilities and interests. This choice helps the achievement of posteducational goals as well. Selecting a suitable academic major is not an easy task. It may sometimes be stressful for undergraduates because they need to consider many factors before taking this decision. However, if they select a college major which suits their capabilities and other preferences it would enhance their satisfaction, career opportunities, academic results and many other life goals (Sarwar and Masood, 2015).

HRM is the practice of recruiting, hiring, developing and managing an organization's employee and therefore, it is a vital part of the organization. Human Resource Management is one of the areas of specialization that undergraduates can select as their academic path. HRM helps an organization in creating, maintaining and improving a dedicated and contended workforce in its progress towards the successful achievement of organizational goals and objectives. Therefore, HRM is a well-recognized field in the business environment. It focuses mainly on enhancing the standards of living of the labour force and facilitating the achievement of organizational success by effectively and efficiently managing that labour force. The Quality Assurance and Accreditation Commission of Sri Lanka has likewise not answered questions concerning the types of courses or subjects that need to be taught, how many courses should be included in the curriculum or the sequence of courses to be taught within semesters and years in HRM degree programs (Opatha, 2019). Many research studies have been done in areas such as Agriculture, Information Technology and Management Information Systems regarding the factors affecting the selection of areas of specialization (Fizer, 2013). However, little attention has been paid, globally or locally, to the factors affecting the selection of HRM as an area of academic specialization. Referring to past studies that have been done on the factors affecting the selection of academic specializations, the present researchers have created the conceptual framework of this study.

\section{Literature Review}

After reviewing several research papers, it was possible to identify some factors that affect the selection of a field of specialization. Those factors related to some specific attitudes of the students. Some influence their personal perceptions, some their career or future plans and some factors impact on their academic perceptions. Likewise, it was possible to identify some common factors that impact students' perceptions. The conceptual framework was developed on this foundation and discussed below are the common factors that influence students' choice of specialization, as found in the literature review. 
Table 1. Common Factors Influence in Students' Choice of Specialization

\begin{tabular}{|c|c|}
\hline Factors & Research Papers \\
\hline Interest in the field & $\begin{array}{ll}\text { - } & \text { Downey, Mcgaughey, \& Roach (2011) } \\
\text { - } & \text { Kim, Markham, \& Cangelosi (2002) } \\
\text { - } & \text { Malgwi, Howe, \& Burnaby (2005) } \\
\text { - } & \text { Fizer (2013) } \\
\text { - } & \text { Sawar \& Masood (2015) } \\
\text { - } & \text { Stair, Danjean, Blackburn, \& Bunch (2016) }\end{array}$ \\
\hline Aptitude in the subject & $\begin{array}{ll}\text { - } & \text { Downey, Mcgaughey \& Roach (2011) } \\
\text { - } & \text { Kim, Markham \& Cangelosi (2002) } \\
\text { - } & \text { Malgwi, Howe, \& Burnaby (2005) } \\
\text { - } & \text { Fizer (2013) } \\
\text { - } & \text { Sawar \& Masood (2015) } \\
\text { - } & \text { Stair, Danjean, Blackburn \& Bunch (2016) } \\
\end{array}$ \\
\hline $\begin{array}{l}\text { Job Characteristics } \\
\text { - Job availability } \\
\text { - Job security } \\
\text { - Employment } \\
\text { opportunities }\end{array}$ & $\begin{array}{ll}\text { - } & \text { Downey, Mcgaughey \& Roach (2011) } \\
\text { - } & \text { Kim, Markham, \& Cangelosi (2002) } \\
\text { - } & \text { Malgwi, Howe, \& Burnaby (2005) } \\
\text { - } & \text { Sawar \& Masood (2015) } \\
\text { - } & \text { Stock \& Stock (2018) } \\
\text { - } & \text { Stair, Danjean, Blackburn, \& Bunch (2016) }\end{array}$ \\
\hline $\begin{array}{l}\text { Others influence } \\
\text { - Family } \\
\text { - } \text { Friends } \\
\text { - Peers } \\
\text { - College instructors } \\
\text { - Lectures }\end{array}$ & $\begin{array}{ll}\text { - } & \text { Downey, Mcgaughey \& Roach (2011) } \\
\text { - } & \text { Kim, Markham \& Cangelosi (2002) } \\
\text { - } & \text { Malgwi, Howe \& Burnaby (2005) } \\
\text { - } & \text { Fizer (2013) } \\
\text { - } & \text { Hussin, Muhammad \& Sukor (2019) } \\
\text { - } & \text { Ana-Andreea, Liviu \& Alina (2013) } \\
\text { - } & \text { Sawar \& Masood ( 2015) } \\
\text { - } & \text { Stock \& Stock (2018) } \\
\text { - } & \text { Stair, Danjean, Blackburn \& Bunch (2016) }\end{array}$ \\
\hline Personality Traits & $\begin{array}{ll}\text { - } & \text { Downey, Mcgaughey \& Roach (2011) } \\
\text { - } & \text { Fizer (2013) } \\
\text { - } & \text { Stair, Danjean, Blackburn, \& Bunch (2016) }\end{array}$ \\
\hline $\begin{array}{l}\text { Level of Pay/ Projected } \\
\text { Salary }\end{array}$ & $\begin{array}{ll}\text { - } & \text { Downey, Mcgaughey \& Roach (2011) } \\
\text { - } & \text { Kim, Markham, \& Cangelosi (2002) } \\
\text { - } & \text { Malgwi, Howe, \& Burnaby (2005) } \\
\text { - } & \text { Fizer (2013) } \\
\text { - } & \text { Sawar \& Masood (2015) } \\
\text { - } & \text { Stock \& Stock (2018) } \\
\text { - } & \text { Stair, Danjean, Blackburn \& Bunch (2016) }\end{array}$ \\
\hline Course Content & $\begin{array}{ll}\text { - } & \text { Hussin, Muhammad \& Sukor (2019) } \\
\text { - } & \text { Sawar \& Masood (2015) }\end{array}$ \\
\hline $\begin{array}{l}\text { Reputation of Subject and } \\
\text { the University }\end{array}$ & $\begin{array}{ll}\text { - } & \text { Kim, Markham, \& Cangelosi (2002) } \\
\text { - } & \text { Malgwi, Howe \& Burnaby (2005) }\end{array}$ \\
\hline
\end{tabular}


- Hussin, Muhammad \& Sukor ( 2019)

- Ana-Andreea, Liviu, \& Alina (2013)

- $\quad$ Stock \& Stock (2018)

- $\quad$ Stair, Danjean, Blackburn \& Bunch(2016)

Quality of Instructors and

- Sawar \& Masood (2015)

Lecturers

- Stair, Danjean, Blackburn, \& Bunch (2016)

Occupational Prestige $\quad$ - Downey, Mcgaughey, \& Roach (2011)

- Sawar \& Masood (2015)

Degree of Difficulty and - Downey, Mcgaughey, \& Roach (2011)

Workload of the Subject $\quad$ - Sawar \& Masood (2015)

Class Size $\bullet$ Stair, Danjean, Blackburn, \& Bunch (2016)

Demographic Variables • Fizer (2013)

- Gender

- Stair, Danjean, Blackburn, \& Bunch (2016)

- Race

- Age

\subsection{Personal Factors}

When many students enter business school, they do not have a proper understanding about the subject or areas suitable for their careers. Therefore, they struggle when they have to make choices (Malgwi, Howe and Burnaby, 2005). The effect of personal characteristics or situation has a large influence on students' decision-making related to selection of specialization (Sarwar and Masood, 2015). Many studies identify factors like interest in the field, aptitude in the field, personal image, personality, student's needs, mental ability, personal goals and motivation as personal factors (Fizar, 2013; Downey, Mcgaughey and Roach, 2011; Malgwi, Howe and Burnaby, 2005; Kim, Markham and Cangelosi, 2002).

Personal goals, aptitude level and most importantly, interest in the subject are some factors that influence the decisions made by a student (Sarwar and Masood, 2015). Interest in the subject was a strong influencing factor for the initial choice of major made by both men and women. Aptitude in the subject strongly impacted women's initial choices but was less influential in men (Malgwi, Howe and Burnaby, 2005). According to the theory of reasoned action advanced by Downey (2011), it was found that a person's attitudes towards the choice of a major significantly influenced his/her intention to work in the major field. Therefore, an academic major should suit the unique interests and needs of individual students (Stock and Stock, 2019).

Most researchers have found that there are individual differences in personality that come into play when choosing an academic major or field of specialization. Individual differences in personality are more important than socialization effects and it seems plausible to assume that personality domains have a significant impact on the intention to enroll in a specific university major (Balsamo, Lauriola and Saggino, 2012). Knowing those factors help students to plan their degree offerings and it helps college advisors to guide them according to their personalities, goals and skills (Stock and Stock, 2019). 


\subsection{Academic Factors}

When students select a field of specialization in higher education, they consider various types of academic criteria. These are educational elements, courses that need to be attended, assignments, perceived difficulty of the program, teachers' characteristics, entry requirements and opportunities to gain practical experience (Bobâlcă, Țugulea and Bradu, 2014). Academic considerations, therefore, have a large impact on students' decisions to select a field of specialization (Sarwar and Masood 2015). Many past studies have found that there are individual differences in personality that influence the choice of an academic major (Balsamo, Lauriola and Saggino, 2012). Students also consider interest in the subject, aptitude in the subject, reputation of the college, parents' wishes, and opinions of high school guidance counselors and high school teachers when choosing their fields of specialization (Malgwi, Howe and Burnaby, 2005).

Selecting a suitable specialization is very important and is not easy. In selecting specialization, most students are influenced by certain factors, namely, academic factors, social capital factors, future prospect factors, human resources factors, market demand factors and job prospect factors, all of which contribute about $47 \%$ to students' decision making related to their field of specialization. Academic factors include quality of the course content, workload, difficulty level of the subject, knowledge limits and the instructor's experience and competency (Sarwar and Masood, 2015). Most universities actively help students to select their fields of specialization. They provide opportunities for students to meet industrial professionals and academic professionals to build up awareness about possible majors that suit their abilities and needs (Stock and Stock, 2019).

When considering bachelor's degrees in Business Management, most Sri Lankan universities focus on specialization in HRM. Therefore, when compiling the educational curriculum in HRM, appropriate location of the courses in the curriculum structure, availability of internship, duration of the internship, availability of independent study, duration of the independent study, coverage of the core skills set, availability of graduate profile and the intensity of the graduate profile should be considered under an objective evaluative framework (Opatha, 2019).

\subsection{Social Factors}

Factors related to the social environment also have a relationship with the decision-making process related to the student's selection of a field of specialization. Here, several interested parties may attempt to influence students to choose a particular specialization or major. For example, families, especially parents, normally encourage or even pressurize their children to pursue a specific degree. Friends also influence students when selecting a major (Sarwar and Masood, 2015). According to one research study, the most important factor influencing management majors was the students' parents (Stock and Stock, 2019). Most often, parents and friends play the roles of primary influencers, but teachers, coaches, lecturers and college instructors also have a huge impact on students' decisions (Wildman and Torres, 2002). Peers are another group of people who influence students. Students are more likely to discuss with and be influenced by their peers when selecting an academic major (Hussin, Muhamad and 


\section{Macrothink}

International Journal of Human Resource Studies

ISSN 2162-3058

2021, Vol. 11, No. 1

Khalil 2019). Therefore, peers have a major influence on students' choice of majors (Fizer 2013). Some social influences on specialization are linked to job characteristics which include job availability, job security and projected salary. Many researchers have found that job security and job availability have a large impact on a student's choice of major when he/she enters college or university as both factors refer to the difficulty or ease of obtaining jobs after graduation and the likely availability of jobs throughout his/her career (Downey, Mcgaughey and Roach, 2011). Governments should ensure that there are sufficient jobs in related fields for students after their graduation, because limited employment opportunities encourage undergraduates to choose majors that provide sufficient preparation for work before moving into the realm of employment (Hussin, Muhamad and Khalil 2019). Further, social image or the prestige or status of the occupation can also affect a student when he/she is in the process of selecting a college major and studies report that students preferred to choose majors and careers endowed with an enhanced social image (Downey, Mcgaughey and Roach 2011).

\section{Conceptual Framework}

After a comprehensive literature review was done, the following conceptual framework was created in order to identify the factors that influence students' selection of the Human Resources Management specialization. At the initial stage of the research, the influential factors will be divided into three categories, namely, Personal Factors, Academic Factors and Social Factors and their impact on the intent to select the HRM specialization will be examined. Personal Factors include interest in the field, aptitude in the subject and the personality traits. The course content, the reputation of the subject and the university will be considered as academic factors, while job characteristics, occupational prestige and others' influence will be considered as social factors. Finally, the impact of all three factors on the intent to specialize in HRM will be examined. This result will be compared with the findings obtained using the impact of personal, academic and social factors on the intention to select HRM. 


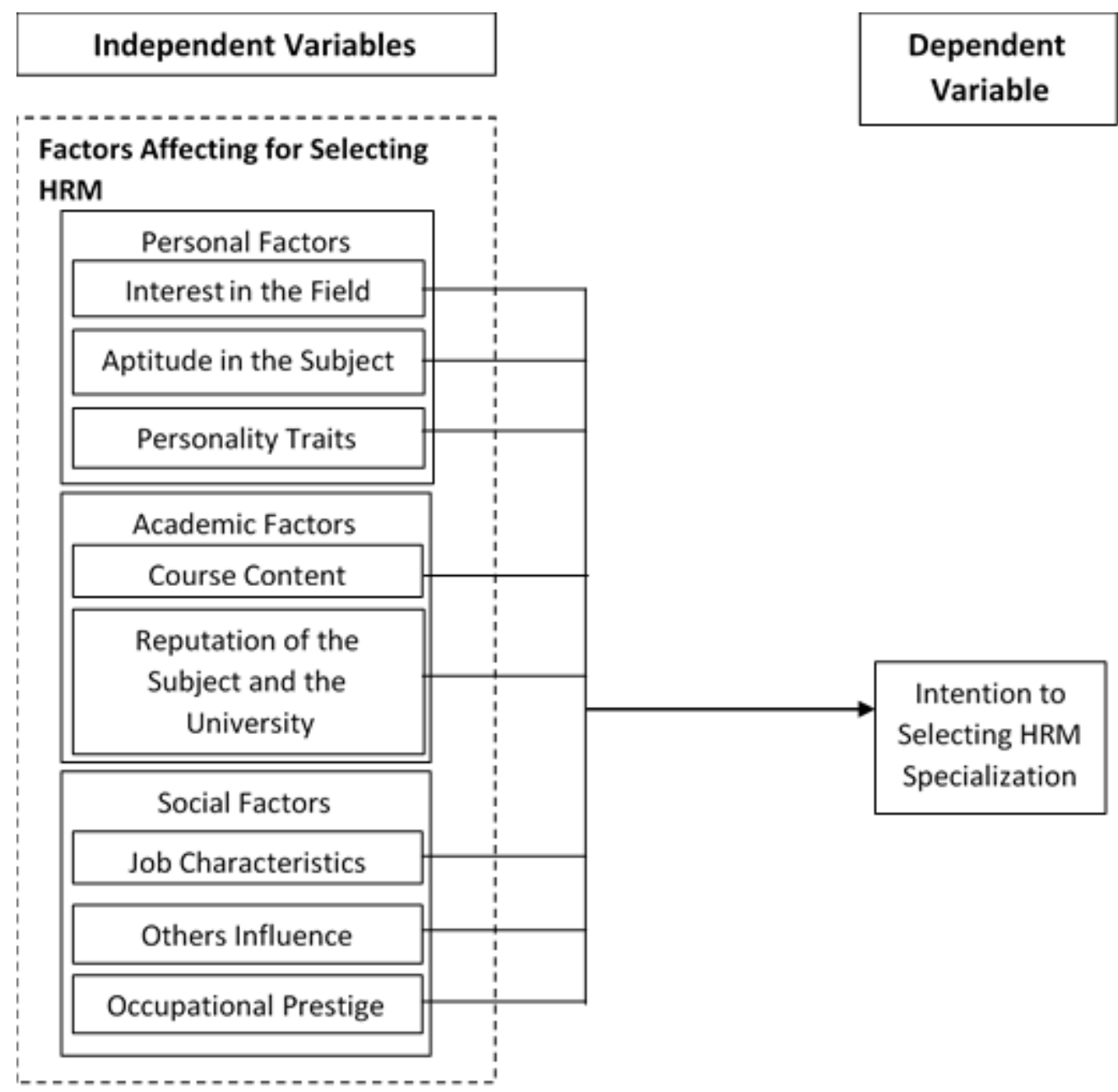

Figure 1. Conceptual Framework

Source: Author Developed

Two hypotheses were identified as follows:

- $\quad \mathbf{H}_{\mathbf{0}}$ - There is no relationship between factors thought to influence the selection of Human Resources Management and the intention to select Human Resources Management Specialization.

- $\quad \mathbf{H}_{\mathbf{1}}-$ There is a relationship between factors thought to influence the selection of Human Resources Management and the intention to select Human Resources Management Specialization.

\section{Conclusions and Implications}

Selecting specialization area is the most important and difficult decision which undergraduates take in their academic life. Human Resource Management is also one of those specialization areas. Researchers have developed a conceptual framework to find the factors affecting for selecting Human Resource Management Specialization with the support of previous research findings. Significance of this study is that it provides logical background to develop hypothesis to test the association between personal, social and academic factors 
towards making decision of selecting Human Resource Management specialization for complete the bachelor's degree. As suggestions to future researchers, they will be able to test the model in universities and prove that there is an association between personal, social, and academic factors when selecting other specialization areas. Further, future researchers can extend this model by adding moderating variables such age and Grade Point Average.

\section{References}

Ajibola, M. O., Emeghe, I. J., Oluwumi, A. O., \& Oni, A. S. (2017). A Study on Students' Choice of Programme in the University. Journal of Educational and Social Research, 7(1), 137-144. https://doi.org/10.5901/jesr.2017.v7n1p137

Al-Lawati, E. H., Subramaniam, R., \& Kumar, R. (2017). An Empirical Study on Factors Influencing Business Students' Choice of Specialization with Reference to Nizwa College of Technology, Oman. International Business Research, 10(9), 177. https://doi.org/10.5539/ibr.v10n9p177

Ana-Andreea, M., Liviu, N. M., \& Alina, M. C. (2013). Factors of Influence in the Choice of a Higher Education Specialization in Romania. Procedia - Social and Behavioral Sciences, 84, 1041-1044. https://doi.org/10.1016/j.sbspro.2013.06.695

Balsamo, M., Lauriola, M., \& Saggino, A. (2012). Personality and College Major Choice: Which Come First? Psychology, 03(05), 399-405. https://doi.org/10.4236/psych.2012.35056

Bobâlcă, C., Țugulea, O., \& Bradu, C. (2014). How are the Students Selecting their Bachelor Specialization? A Qualitative Approach. Procedia Economics and Finance, 15, 894-902. https://doi.org/10.1016/S2212-5671(14)00553-X

Downey, J. P., Mcgaughey, R., \& Roach, D. (2011). Attitudes and Influences toward Choosing a Business Major: The Case of Information Systems. Journal of Information Technology Education: Research, 10, 231-251. https://doi.org/10.28945/1502

Fizer, D. (2013). Factors Affecting Career Choices of Collage Students Enrolled in Agriculture. 1-34.

Hussin, N. L., Muhamad, N., \& Sukor, M. (2019). Review Paper: Determinants of Students' Choice of Courses and University Selection. Journal of Business Innovation, 4(2), 71-78.

Kim, D., Markham, F. S., \& Cangelosi, J. D. (2002). Why Students Pursue the Business Degree: A Comparison of Business Majors Across Universities. Journal of Education for Business, 78(1), 28-32. https://doi.org/10.1080/08832320209599694

Malgwi, C. A., Howe, M. A., \& Burnaby, P. A. (2005). Influences on Students' Choice of College Major. Journal of Education for Business, 80(5), 275-282. https://doi.org/10.3200/JOEB.80.5.275-282

Montmarquette, C., Cannings, K., \& Mahseredjian, S. (2002). How do young people choose college majors? Economics of Education Review, 21(6), 543-556. https://doi.org/10.1016/S0272-7757(01)00054-1

Opatha. (2019). A Study of Bachelor's Degrees in Human Resource Management in Three Sri Lankan Leading State Universities. Universal Journal of Educational Research, 7(11), 2361-2371. https://doi.org/10.13189/ujer.2019.071114 
Sarwar, A., \& Masood, R. (2015). (PDF) Factors Affecting Selection of Specialization By Business Graduates. Retrieved January 09, 2020, from https://www.researchgate.net/publication/320757652_Factors_Affecting_Selection_Of_Speci alization_By_Business_Graduates

Stair, K., Danjean, S., Blackburn, J. J., \& Bunch, J. C. (2016). A Major Decision: Identifying Factors that Influence Agriculture Students' Choice of Academic Major. Journal of Human Sciences and Extension, 4(2), 111-125.

Stock, P. A., \& Stock, E. M. (2019). Factors that Influence a Collage Student's Choice of an Academic Major and Minor. 1-11.

\section{Copyright Disclaimer}

Copyright for this article is retained by the author(s), with first publication rights granted to the journal.

This is an open-access article distributed under the terms and conditions of the Creative Commons Attribution license (http://creativecommons.org/licenses/by/4.0/). 